\title{
HIGH INTENSITY INTERVAL TRAINING (HIIT) PROMOTES SIMILAR HEALTH BENEFITS AND WEIGHT-LOSS IN A FRACTION OF THE TIME COMPARED TO STEADY-STATE CARDIO.
}

\author{
How can we implement HIIT in a real-world setting to reap the benefits?
}

\section{A MAGAS INTENZITÁSÚ INTERVALLUMOS EDZÉS (HIIT) AZ ÁLLANDÓ INTENZITÁSÚ KARDIÓHOZ HASONLÍTVA MEGEGYEZŌ EGÉSZSÉGVÉdō ÉS SÚLYCSÖKKENTŌ HATÁSSAL BíR, ÉS MINDEZT AZ IDŌ TÖREDÉKE ALATT TESZI.}

\author{
Hogyan tudjuk a HIIT-t a mindennapokba átvinni, \\ hogy ezeket a pozitív hatásokat megtapasztaljuk?
}

ÖSSZEFOGLALÁS: A magas intenzitású intervallumos edzés azoknak lehet hatásos módszer, akik rövidebb időbefektetéssel szeretnének súlyt veszteni és kardiovaszkuláris egészségüket javítani, mint ami lehetséges mérsékelt intenzitású kardióval (SSC). Bizonyítást nyert, hogy az állandó intenzitású kardió segíti a metabolikus és szívérrendszeri panaszokat, és mint ilyen, a súly, vércukor (Warbourton, 2006b; Boutcher, 2011; Boule et al, 2001) és vérnyomás kontroljában játszik fontos szerepet (Skutnik et al, 2016). HIIT tréningnek sikerült hasonló eredményeket felmutatnia (Falcone et al, 2015; Jelleyman et al, 2015; Rognmo et al, 2004; Little et al, 2011) csupán feleannyi (Hood et al, 2011, Garber et al, 2011), illetve az idő egyharmada alatt (Skutnik et al, 2016). Az intervallumos edzés módszere nem egy új elképzelés, a Wingate protokolt 1974-ben kutatási célokkal mutatták be, azóta már rengeteg különböző formája használatos. Az utóbbi évtizedekben az egészséggel fog- lalkozó szakemberek az American College of Sports Medicine ajánlását követték a mérsékelt intenzitású kardió edzés terén, amely minimum 150 percet ajánlott ebból hetente az átlagos mozogni kívánónak (Whaley, 2006). 2011-ben kiterjesztették ajánlásukat a magas intenzitású, élénk szív és légzőszervet is megdolgoztató gyakorlatokra. A javaslatuk magába foglal minimum 20 perc magas intenzitású edzést háromszor egy héten, a HIIT-et is ideértve, ideális esetben összesen 75 percben egy héten. Ez egy nagyon fontos lépés, mivel a legfőbb ok, ami visszatartja az emberek többségét a rendszeres testmozgástól, az az idő hiánya (Gillen - Gibala, 2011; Skutnik et al, 2016). Ez a cikk szeretné az ajánlás kutatáson alapuló okait felfedni és a HIIT mindennapokban való tényleges használatának lehetőségeit vizsgálni.

Kulcsszavak: Magas intenzitású intervallumos edzés, szív és érrendszer egészségi állapota, súlycsökkenés, élénk mozgás, időhiány

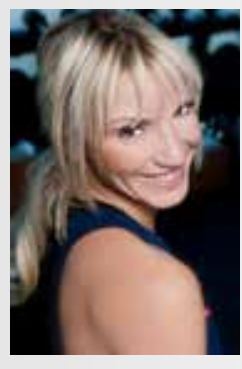

Szerző:

Ressinka Judit

Title: Personal Trainer, Strength

\& Conditioning Coach Munkahelye: Myhealthcare

Clinic, Wandsworth www.movepainfree.co.uk juditressinkapt@gmail.com Fő́bb kutatási területei: fájdalommentes mozgás Fotók: a szerző felvételei
ABSTRACT: High intensity interval training may be beneficial to those who want to lose weight and gain cardiovascular health benefits in a shorter amount of time compared to moderate intensity steadystate cardio (SSC). It has been confirmed that SSC can promote metabolic and cardiovascular health and so have been at the forefront of weight, blood glucose (Warbourton, 2006b; Boutcher, 2011; Boule et al, 2001) and blood pressure control (Skutnik et al, 2016). HIIT has made claims to achieve similar results (Falcone et al, 2015; Jelleyman et al, 2015; Rognmo et al, 2004; Little et al, 2011) in just half (Hood et al, 2011, Garber et al, 2011) or one-third of the time (Skutnik et al, 2016). The idea of interval training is not a new concept, the Wingate protocol has been introduced for research purposes in 1974, however, nowadays there are lots of different types of high intensity interval trainings used. In recent decades, health practitioners have followed the exercise recommendations of the American College of Sports Medicine on moderate intensity exercise, which said to be minimum of 150 minutes for the wider public (Whaley, 2006). In 2011, they have extended this onto vigorous intensity cardiorespiratory exercise. Their recommendation is three times a week of minimum 20 minutes vigorous exercise, such as HIIT, ideally totalling 75 minutes a week. This is a very important step, as the primary reason preventing individuals from exercising is said to be lack of time (Gillen Gibala, 2011; Skutnik et al, 2016). This article would like to look at the research-based reasoning behind this recommendation and the actual implementation of HIIT. Keywords: High Intensity Interval Training, cardiovascular health, weight loss, vigorous exercise, lack of time 


\section{Introduction}

Many sports are, for the most part, undertaken in an intermittent high-intensity fashion. In preparing for intermittent sports, various forms of high-intensity interval training (HIIT) are often used to improve cardiorespiratory and metabolic function as well as physical and sports performance. Therefore it was feasible to develop fitness tests and protocols that mimic this fashion and help to prepare athletes for competition. The general public can now also benefit from the positive effects of HIIT with several different protocols varying in duration, intensity, volume and recovery, though some of the most intense forms of this exercise modality seem to be too challenging and might be unsafe for the sedentary public (Gillen - Gibala, 2014). The American College of Sports Medicine (ACSM) recommendations were clear on how much physical activity most, apparently healthy, adults of all ages should engage in each week to promote health benefits. The minimum time was said to be 150 minutes a week of moderate intensity cardiorespiratory exercise, consisting of ideally five separate exercise sessions, of at least 30 minutes each. This was already asking too much from most as far time commitment goes.

HIIT is a broad term for workouts that involve short periods of intense exercise alternated with low intensity or complete rest periods for recovery. Typically, a workout will range from 10-30 minutes in duration including warm up and cool down. The intensity varies from the Wingate type of anaerobic maximal effort, referred to as 'all out' - pushing beyond $100 \%$ maximal aerobic capacity (VO2Max) - 30 seconds ergonometer sprints protocols for a total of four to six repetitions (Whyte et al, 2010) to sub-maximal 3-5 minutes aerobic running intervals. This latter form of HIIT has been described as "aerobic interval training". The actual activity being performed can vary but could include cycling, running, jump rope, battling rope, free weights and body weight exercises (Figure 2). Studies have been included here mostly engaged their subjects within the range of submaximal vigorous exercise intensities according to ACSM guidelines, at $65-90 \%$ VO2max and/or 77 $-95 \%$ HRmax (Garber et al, 2011) and used a stationary bike, treadmill, run-

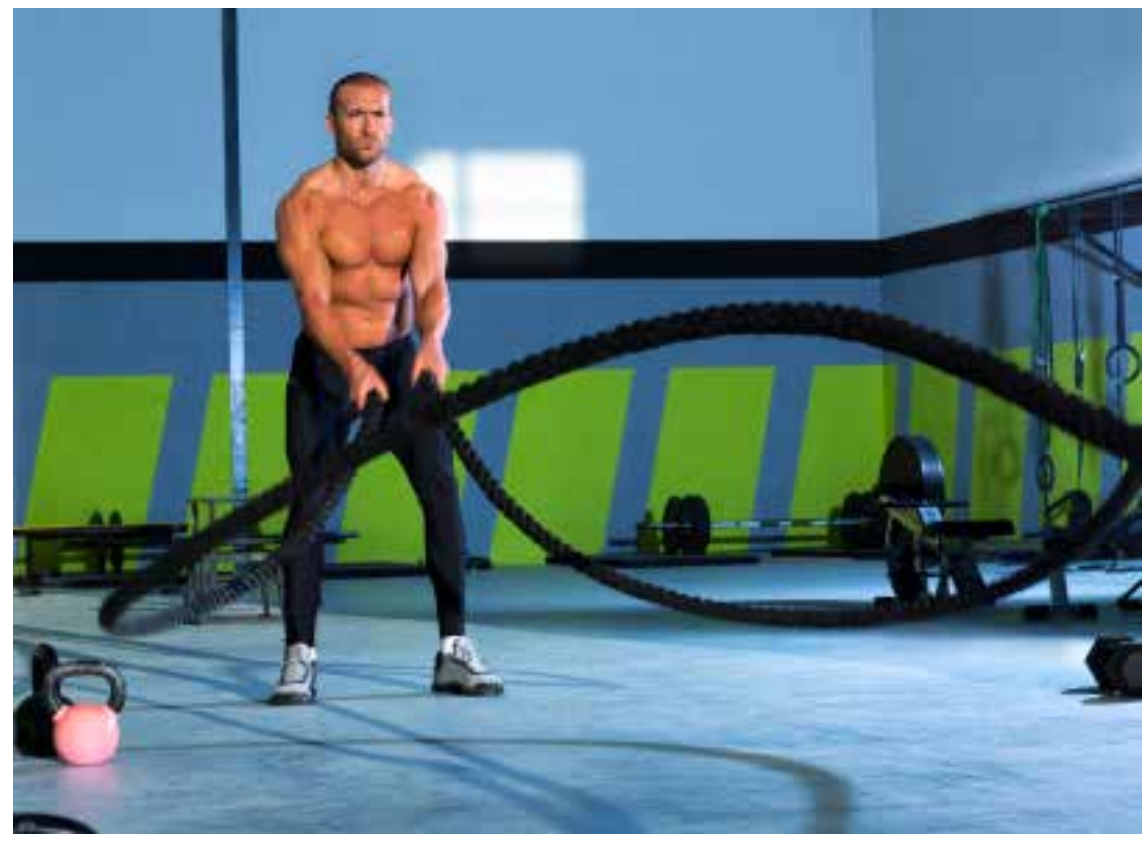

ning track or hydraulic resistance device. For this overview selected studies have been using sedentary, less active or recreationally trained individuals as subjects for their investigations. Generally in trained individuals the ideal intensity is above $90 \%$ VO2max or at or above 100\% VO2max for HIIT.

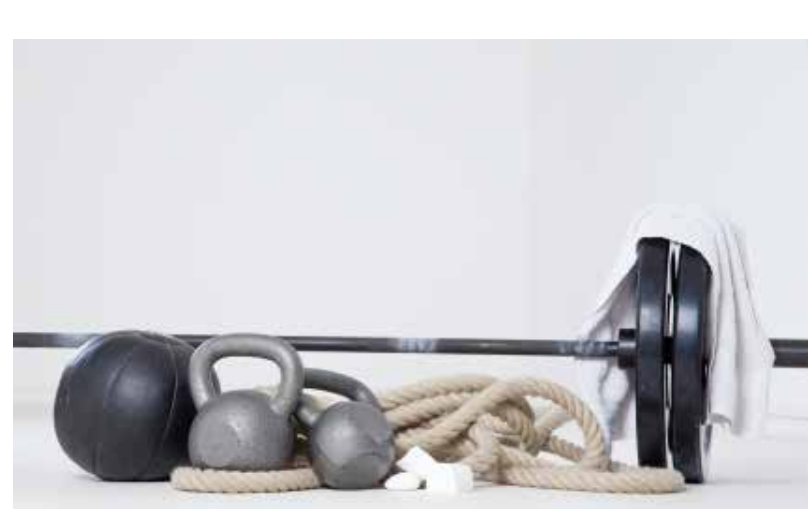

Figure 2.

\section{Weight Management}

Weight-loss can be approached with such clinical terms as calories burnt, energy expenditure (EE), excess post-exercise calorie consumption (EPOC), decrease of abdominal adiposity and increased fat oxidisation. Most studies suggest that because of the short duration of HIIT sessions they don't elicit high energy expenditure compared to other forms of exercises, it appears that the real calorie-burning effect comes post-exercise. It appears that the similar changes in body composition to those of endurance training and resistance training (Macpherson et al, 2011; Whyte et al, 2010), and the higher rates of fat oxidation could be attributed to EPOC (Macpherson et al, 2011, Boutcher 2011, Hazell, 2012).

Despite the difference in total exercise volume and smaller time commitment, 24-hour energy expenditure would be similar between HIIT and endurance treatments, and greater compared with the control (Skelly, 2012) the same was found by Hazell et al, (2012), who showed that total $\mathrm{O} 2$ consumption over 24 hours was similar after a bout of Wingate-based HIIT and a 30-min endurance bout. Williams et al, (2013) measured EPOC for 3 hours following exercise and found no differences between all-out HIIT and the endurance protocol.

Although it has been noted that there was also one study where HIIT burnt $25-30 \%$ more calories during the session doing 20 sec maximum effort 40 sec rest for 30 minutes - for 10 minutes actual work - compared to 30 minutes resistance training at $75 \%$ of their 1RM, endurance cycling and endurance treadmill at 70\% HRmax (Falcone et al, 2015) this hasn't been repeated elsewhere and could be attributed to the fact that recreationally active participants performed the exercises, not sedentary people and also to the unusually high number of work intervals in the protocol. 

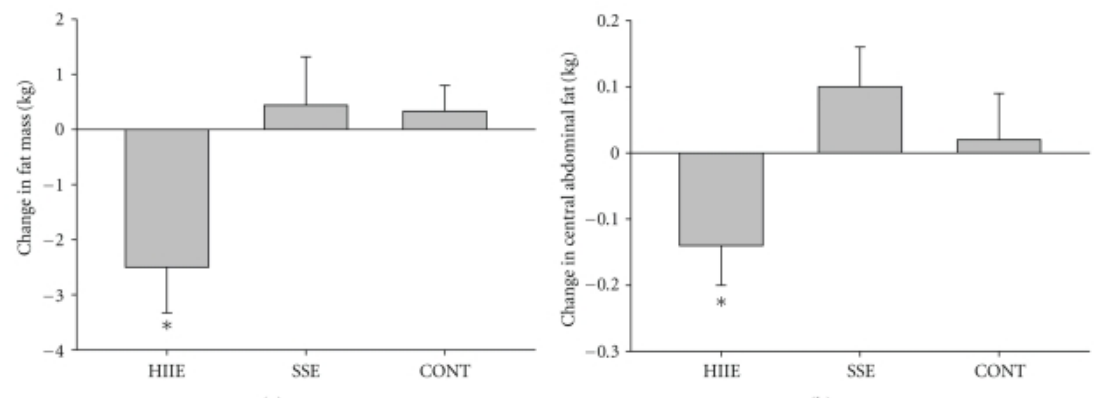

(a)

Figure 3. Total fat change (a) and change in central abdominal fat (b) for the high intensity intermitten exercise group (HIIE) was significantly different from the steady-state group (SSE) and the control group CONT) (Trapp et al. 2008).

Trapp et al, (2008) also found that 15 weeks of all-out HIIT three times a week for 20 minutes was superior to endurance work for reducing subcutaneous and abdominal fat mass in inactive women (Figure 3). HIIT consisting of 8 seconds sprints and 12 seconds low intensity cycling compared to $60 \% \mathrm{VO} 2$ max steadystate cycling reduced subcutaneous fat with an extra $2.5 \mathrm{~kg}$.

Other studies employing all-out protocols have reported reductions in waist circumference and fat mass and increase in fat oxidisation following just 2-6 weeks of HIIT that were similar to those changes for endurance training (Whyte et al, 201O; Macpherson et al, 2011). However these latter studies did not find any difference seen in the Trapp study in weight-loss for individuals performing moderate-intensity versus vigorous-intensity exercise. When it comes to energy expenditure post-exercise two identical protocols found the same for post measurements for energy expenditure.

One where 20minutes - $10 \times 60$ seconds work, 60 seconds rest, at $85^{-}$ 95\% HRR running - HIIT produced greater resting energy expenditure than an aerobic endurance exercise of 30 minutes and high-intensity resistance training (HIRT) in 25 minutes (Wingfield et al, 2015) (Figure 4).

In an other study, consisting with 10 $\times 60$ sec efforts at an intensity eliciting 90\% maximal heart rate (HRmax), interspersed with 60 sec of active recovery cycling, has been shown to induce similar energy expenditure post-exercise to the endurance exercise at 70\% HRmax for 50 minutes (Skelly et al, 2012) these results are also comparable to Wingate-based all out protocols and endurance training protocols (Little et al, 2011; Gillen et al, 2013).

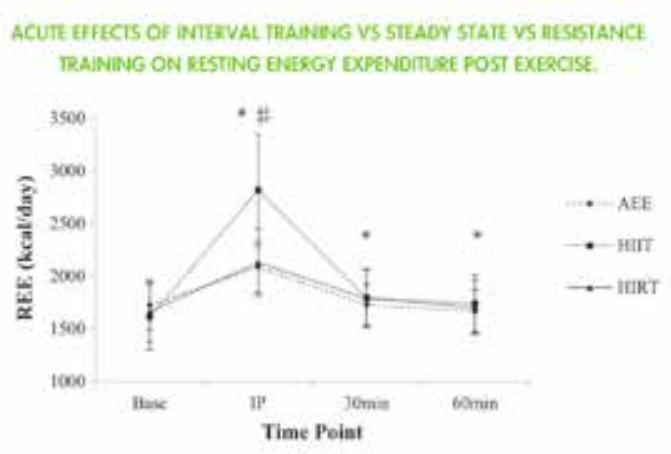

Figure 4. When comparing resting energy expenditure (RRE) of the HIIT protocol to the steady state running (AEE) immediately after (IP) the session there was a significantly larger EPOC compared to the AEE and HIRT protocols. Even at 30 and at 60 minutes post, there was a $189.2 \mathrm{kcal} /$ day difference in energy compared to AEE (Wingfield et al, 2015).

These studies suggest that over 24 hours equal or larger amount of calories are burnt by different HIIT protocols or that equal or greater weightloss is achievable with HIIT protocols for the untrained population. Therefore, the suggestions that HIIT may be a time-efficient alternative to endurance training in this regard are founded (Boutcher 2011).

\section{Cardiovascular Fitness}

A revealing study emerged well before the 2011 ACSM guidelines got published. Dr. Williams' study suggests that developing a high VO2max, that represents cardiovascular fitness level, is more important than merely engaging in moderate-intensity physical activity. This meta-analysis suggest that those who are performing vigorous exercise rather than just moderate intensity, acquiring improved fitness and higher VO2max, lower their risk of developing cardiovascular disease (CHD) significantly even in comparison to moderate intensity exercisers. So it seems that someone's aerobic fitness, aerobic capacity is massively important to keep cardio-metabolic health risk levels lower (Rognmo et al. 2004).

Clinical trials supported the above by showing that exercise performed at a vigorous intensity may provide greater improvements than moderate-intensity exercise in some CHD risk factors, such as increased aerobic fitness, improved glucose control and decreased resting blood pressure (Swain 2006a; Warbourton 2005). There might be no difference in weight-loss for individuals performing moderate-intensity versus vigorous-intensity exercise, as when it comes to weight-loss, a calorie is a calorie, regardless of how it is burned. But it seems that for aerobic fitness and CHD risk, not all calories are created equal. Further research is needed to explore the effect of various exercise intensities on individual CHD risk factors, but the current evidence supports greater improvements with vigorous-intensity compared with moderate-intensity exercise (Swain, 2006b).

An example of a more recent study is an 8-week low-volume HIIT cycling protocol of 20 minutes work 1:1, 3 times a week at $60 \%$ Peak Power (10orpm) (6o minutes in total) and endurance exercise of 30 minutes, 4 times a week (12O minutes in total) at $40 \%$ of VO2max reserve (6orpm) which both could induce the same training adaptations such as decreased arterial pressure and 25\% increased VO2Max in pre-hypertensive individuals (Skutnik et al, 2016). An important finding was that only HIIT decreased C-reactive protein (CRP, a systematic inflammation indicator) levels significantly, which is a similarly good predictor of cardiovascular problems, as is cholesterol.

Caution is needed with cardiac patients and those who may have CHD, as one study found that when sedentary individuals with CHD suddenly exercised vigorously ( $\geq 6$ METS $-1 M E T$ is the energy expenditure at rest), their risk of experiencing a heart attack increased more than 100-fold above rest (Mittleman et al, 1993). However, it is reassuring that this increased risk was only about two-fold for those who normally exercised several times per week. Therefore, although exercise is beneficial to cardiac patients, profes- 
sionals need to be cautious when first beginning exercise programs for these special populations.

These results suggest that HIIT could be a time-efficient alternative to endurance training in improving cardiovascular and cardio-metabolic health.

\section{HIIT in a Real-World Setting}

In controlled experimental settings very different HIIT protocols showed to be remarkably effective for increasing cardio-respiratory fitness, reducing cardio-metabolic risk factors and reducing body fat to the same or greater extent as steady-state cardio and weight training. The purpose of the following studies were to extend and translate the HIIT concept into real-world settings for indoor and outdoor training.

In terms of minimal time commitment needed for HIIT outside a laboratory, a minimum of 8 weeks (Skutnik et al, 2016) or 12 weeks (Lunt et al, 2014) three times a week, training have been suggested to produce significant changes in anthropomorphic measures such as reduction in body fat mass, reduction in abdominal and trunk adiposity and visceral fat. However it is important to note that clinically meaningful cardio-respiratory measures such as VO2 max showed moderate changes in the 12-weeks study in the aerobic interval training group $(1.01 \mathrm{ml} / \mathrm{min} / \mathrm{kg}$ VO2max) while the walking group and maximal-effort interval training group's VO2max even got reduced, probably due to low adherence to exercise and the low attendance of the aerobic interval training group. The actual time spent exercising was 74 minutes for aerobic interval training, 45 minutes for maximal volitional interval training and 116 minutes for walking on average including 10 minutes warm ups and 5 minutes cool downs.

It is understood that those changes that have been achieved in a short period of time won't last long either, longer time commitment and therefore longer studies are needed to show whether these improvements above show progression on the long term or we are experiencing a quick initial response to HIIT. Roy et al, 2018 attempted to examine just that with a 12 months of unsupervised HIIT training protocol. The results showed only moderate changes in body fat loss and VO2max. The downsides of this study were insufficient monitoring of participants and also the lack of progression in the programs. Fall-outs were high, from the 105 people in the group 24 remained adherent to the 2 or more HIIT sessions a week after a year. Also results have likely been affected by the lack of motivation in subjects needing to perform this form of difficult exercise on their own as compared to clinical settings. For further field studies a higher number of participants and longer supervised times are needed to get really meaningful data and narrower confidence intervals (Heydari et al, 2012) (Figure 5). Even though it's a difficult form of exercise, those who adhered to it tend to score higher on the Physical Activity Enjoyment Scales (PAES) (Falcone et al, 2015; Kong et al, 2016; Roy et al, 2018).

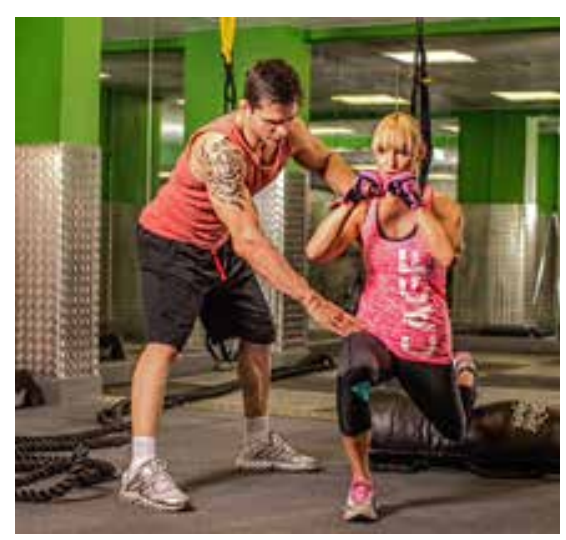

Superwised time

HIIT using the whole body (for ex. squat jumps, burpees, strong man exercises) as the resistive force could be a cost-effective and practical way of exercising even at home, however the efficient application of it needs some consideration. Safe strategies for progression could be prescribed by changing training variables such as gradually increasing stimulus time (10 sec - $1 \mathrm{~min}$ ), decreasing recovery time (1o sec - 2min) and/or increasing total session time (4 - $30 \mathrm{~min}$ ) for beginners, intermediates and advanced individuals (Machado et al, 2017). Under supervision even the vigorous form of 30 sec all-outs (Lunt et al, 2014) could be considered for special populations. There is a very limited amount in research in real-life settings but if we want to draw of any kind of conclusion it seems that with progressive load and volume everybody could benefit from this form of exercise.

\section{Recommendations}

The specific amount of time the exercise, more importantly the rest period, should take will depend on individuals current fitness level and how intensely they like to exercise. In my experience, a time efficient low to medium volume, close to maximal effort HIIT protocol, such us 20 seconds on 60 seconds off for 4-6 times, could work for most untrained individuals as a start, although this option hasn't been taken into consideration in the above studies, yet untrained individuals lose form very quickly when fatigued in close to maximal effort activities, hence the likeliness of injuries will increase with longer intervals (REF). The required intensity can be translated to a target $65 \%$ to $90 \%$ HRmax. A short 20 seconds interval should keep most individuals in good form and not least motivated. Furthermore, a 1:3 work-rest ratio is a good start to allow sufficient recovery after intense work and produces better form interval after interval. As participants get fitter for progression number of repetitions and/or duration of intervals can be increased, while the length of recovery can be decreased gradually (Lunt et al, 2014). After the client has adjusted to the higher intensity, the volume can be increased. However it is unsure from the research articles mentioned here how long a warm up and cool down should be to keep previously inactive participants safe from injury, as an unfavourable example is the 12 week real-world study with 10 minutes warm up, where 3 participants out of the 16 got injury related to HIIT training (8sec sprints) (Lunt et al, 2014). When prescribing vigorous-intensity exercise, one also must be aware of a higher risk for musculoskeletal complications and overuse injuries, particularly with modes of exercise that involve significant impact, such as running. Considering all the above, and that a thorough warm up of 15-20 minutes (for exp. foam rolling, dynamic stretching, muscle activation and jogging) and 5 minutes cool down will be important (ACSM Whayley, 2006) a session will last 25-40 minutes. This time frame is still shorter than that for endurance training sessions, which also need thorough warm-ups due to the highly repetitive nature of them. As far as monitoring calorie expenditure goes, this could be calculated by using online calculators where the average heart 
rate during the training, the duration of the session, age and body weight is needed. Finally, vigorous exercise sessions may be interspersed with moderate-intensity physical activities, functional training, core training, stretching and recreational pursuits to provide a well-rounded regimen ( $A C S M)$.

\section{Conclusion}

High intensity intermittent training (HIIT) is a form of exercise that has been shown to significantly assist in losing fat and increasing fitness in a time efficient manner. Considering the rising rates of obesity and co-morbid health problems such as cardiovascular disease, type II diabetes and metabolic syndrome it is extremely important that people receive education about the benefits of exercise, including HIIT. Accumulating sufficient weekly caloric expenditure at a moderate intensity of exercise is effective for sedentary individuals to achieve weight-loss goals, make modest improvements in aerobic fitness, and experience some reduction in CHD risk. However, it has been shown that the main reason for inactivity and the inability to meet minimum exercise

\section{References:}

Boule, N.G. - Haddad, E. - Kenny, G.P. - Wells, G. (2001): Effects of exercise on glycemic control and body mass in type 2 diabetes mellitus. A meta-analysis of controlled clinical trials. 2 diabetes mellitus. A meta-analysis of controlled clinical trials. 10. 1218-27. DOI:: 10.1034/j.1600-0838.2002.120111_3.x

Boutcher, S.H. (2011): High-intensity intermittent exercise and fat loss. Journal of Obesity. 2011. 4. Journal ID: 868305. DOI:: 10.1155/2011/868305

Falcone, P.H. - Tai, Chih-Yin. - Carson, L.R. - Joy, J.M - Mosman, M.M. - McCann, T.R. - Crona, K.P. - Kim, M.P. Moon, J.R. (2015): Caloric Expenditure of Aerobic, Resistance, or Combined High-Intensity Interval Training Using a Hydraulic Resistance System in Healthy Men. Journal of Strength and Conditioning Research. 29. 3. 779-785. DOI:: 10.1519/ JSC.0000000000000661

Garber, C.E. - Blissmer, B. - Deschenes, M.R. - Franklin B.A. - Lamonte, M.J. - Lee, I.M. - Nieman, D.C. - Swain, D.P. B.A. - Lamonte, M.J. - Lee, I.M. - Nieman, D.C. - Swain, D.P.
(2011): American College of Sports Medicine position stand. (2011): American College of Sports Medicine position stand. Quantity and quality of exercise for developing and maintaining cardiorespiratory, musculoskeletal, and neuromotor fitness in apparently healthy adults: guidance for prescribing exercise. DOI:: 10.1249/MSS.0b013e318213fefb

Gillen, J.B. - Percival, M.E. - Ludzki, A. - Tarnopolsky, M.A. - Gibala, M.J. (2013): Interval training in the fed or fasted state improves body composition and muscle oxidative capacity in overweight women. Obesity (Silver Spring), 21. 11. 22492255. o. DOI:: 10.1002/oby.20379.

Gillen, J.B. - Gibala, M.J. (2014): Is high-intensity interval training a time-efficient exercise strategy to improve healt and fitness? Applied Physiology Nutrition and Metabolisom. 39. 3. 409-412. o. DOI:: 10.1139/apnm-2013-0187

Jelleyman, C. - Yate, T. - O'Donovan, G. - King, J.A. Khunti, K. - Davies, M. J. (2015): The effects of high-intensity interval training on glucose regulation and insulin resistance: a meta-analysis, Obesity Reviews, 16. 11. 942-961. DOI: org/10.1111/obr.12317

Hazell, T.J. - Olver, T.D. - Hamilton, C.D. -Lemon, P.W.R. (2012): Two minutes of sprint-interval exercise elicits 24-hr oxygen consumption to that of $30 \mathrm{~min}$ of continuous endurance exercise. International Journal of Sport Nutrition and Exercise Metabolism. 22. 4. 276-283. o.

Heydari, M. - Freund, J. - Boutcher, S.H. (2012): The effect of high-intensity intermittent exercise on body composition of overweight young males. Journal of Obesity. 2012: 480467. DOI:: 10.1155/2012/480467

Hood, M.S. - Little, J.P. - Tarnopolsky, M.A. - Myslik, F. Gibala, M.J. (2011): Low-volume interval training improves muscle oxidative capacity in sedentary adults. Medicine \& muscle oxidative capacity in sedentary adults. Medicine \&
Science in Sports \& Exercise. 43. 10. 1849-1856. o. DOI:: 10.1249/MSS.0b013e3182199834. guidelines is lack of time, exercise prescription innovations that yield the benefits of long duration exercise has a potentially valuable place in the public's exercise practice and should be used and promoted in keeping the population active. It seems that those who are overweight or obese and those with borderline or already existing diseases benefit the most from HIIT intervention in clinical settings. The length of the studies mentioned above has been 4-15 weeks. Longer studies are needed but it is really promising to see that such short timeframes already work. Individuals interested in increasing their fitness and gaining additional cardiovascular benefits should progress to a vigorous level of intensity, provided they can do so safely. The Wingate type of protocol, although particularly effective $(R E F)$, might not be suitable for sedentary people or for those with previous injuries therefore a more progressive example has been presented to start training at higher intensities. Future studies should investigate whether or not HIIT is a sustainable long-term exercise option for non-supervised individuals who are performing HIIT in real world envi-

Kong, Z - Fan, X - Sun, S. - Song, L. - Shi, Q - Nie, J. (2016): Comparison of High-Intensity Interval Training and Moderate-to-Vigorous Continuous Training for Cardiometabolic Health and Exercise Enjoyment in Obese Young Women: A Randomized Controlled Trial. PLoS One. 1.11.7. e0158589. DOI:: 10.1371/journal.pone.0158589.

Little, J.P. - Gillen, J.B. - Percival, M.E. - Safdar, A. - Tarnopolskly, M.A. - Punthakee, Z. (2011): Low-volume high-intensity interval training reduces hyperglycemia and increase muscle mitochondria capacity in patients with type 2 diabetes. Journal of Applied Physiology. 111. 6. 1554-1560. DOI: 10.1152/ japplphysiol.00921.2011.

Lunt, H. - Draper, N. - Marshall, H.C. - Logan, F.J. - Hamlin, M.J. - Shearman, J.P. - Cotter, J.D. - kimber, N. E. - Blackwell, G. -Frampton, C.M.A. (2014): High Intensity Interva Training in a Real World Setting: A Randomized Controlled Feasibility Study in Overweight Inactive Adults, Measurin Change in Maximal Oxygen Uptake. PLoS One. 9. 1. e83256. DOI:: 10.1371/journal.pone.0083256

Machado, A.F. - Baker, J.S. - Figueira, A.J. - Bocalini, D.S. (2017): High intensity interval training using whole body exercises: training recommendations and methodologica overview. Clinical Physiology and Functional Imaging. DOI: 10.1111/cpf.12433

Macpherson, R.E.K. - Hazell, T.J. - Olver, T.D. - Paterson, D.H. - Lemon, P.W.R. (2011): Run sprint interval training improves aerobic performance but not maximal cardiac output. Medicine and Science in Sports and Exercise. 43. 1. 115-122. o. DOI:: 10.1249/MSS.0b013e3181e5eacd.

Mittleman, M.A. - MaClure, M. - Tofler, G.H. - Sherwood, .B. - Goldberg, R.J. - Muller, J.A. (1993): Triggering of acute myocardial infarction by heavy physical exertion. New England Journal of Medicine. 329. 1677-1683. o. DOI:: 10.1056/ NEJM199312023292301

Rognmo, O. - Hetland, E. - Helgerud, J. - Hoff, J. (2004): High intensity aerobic interval exercise is superior to moderate intensity exercise for increasing aerobic capacity in patients with coronary heart disease. European Journal of Cardiovascular Prevention and Rehabilitation.11. 3. 216 22. DOI:: 10.1097/01.hjr.0000131677.96762.0c

Roy, M. - Williams, S.M. - Brown, R.C. - Meredith-Jones, K.A. - Osborne, H. - Jospe, M. - Taylor, R.W. (2018): High-Intensity Interval Training in the Real World. Outcomes from 12-Month Intervention in Overweight Adults. Medicine \& Science in Sports \& Exercise. 50. 9. 1818-1826. o. DOI:: 10.1249/ MSS.0000000000001642

Skelly, L.E. - Andrews, P.C. - Gillen, J.B. - Martin, B.J - Percival, M.E. - Gibala, M.J. (2014): High-intensity interval exercise induces 24-h energy expenditure similar to traditional en durance exercise despite reduced time commitment. Applie Physiology, Nutrition and Metabolism. 39. 7. 845-848. o. DOI: 10.1139/apnm-2013-0562. ronments (Gillen and Gibala, 2013). Some of the studies have been quite short it remains to be determined whether similar adaptations are to be found with several months of high intensity interval training. It can be stipulated that the high intensity of this type of training produces quick adaptation while endurance training takes longer for adaptations to show (Gillen and Gibala, 2014).

Note: Individuals with symptoms or disease should not consider vigorous-intensity exercise until having completed a physician-approved, moderate-intensity exercise program and obtained further clearance to increase intensity. Moreover, individuals who are without symptoms or disease, but who have a high risk of CHD, may begin a moderate-intensity exercise program but should seek physician clearance before beginning vigorous-intensity exercise. Although most clients can eventually enter a vigorous-intensity program, only individuals who are young (men, <45 years; women, <55 years) and have a low risk for $\mathrm{CHD}$ (no more than one major risk factor) should do so without first obtaining physician clearance.

Skutnik, B.C. - Smith, J.R. - Johnson, A.M. - Kurti, S.P. Harms, C.A. (2016): The Effect of Low Volume Interval Training on Resting Blood Pressure in Pre-hypertensive Subjects: A Preliminary Study. Physician and Sportsmedicine, 44. 2. 177-183. o. DOI:: 10.1080/00913847.2016.1159501

Swain, D.P. - Franklin, B.A. (2006a): Comparison of cardioprotective benefits of vigorous vs. moderate intensity aerobic exercise. American Journal of Cardiology 97. 1. 141-147. o. DOI:: 10.1016/j.amjcard.2005.07.130

Swain, D.P. (2006b): Moderate- or Vigorous-Intensity Exercise: What Should We Prescribe? ACSM's Health \& Fitness Journal. 10. 5. 7-11. 0. DOI:: 10.1249/01. \& Fitness Journal. 10.

Trapp, E.G. - Chisholm, D.J. - Freund, J.- Boutcher, S.H. (2008): The effects of high-intensity intermittent exercise training on fat loss and fasting insulin levels of young women. International Journal of Obesity. 32. 4. 684-691. DOI: 10.1038/sj.ijo.0803781

Warburton, D.E.R. - McKenzie, D.C. - Haykowsky, M.J. -Taylor, A. - Shoemaker, P. - Ignaszewski, A.P. (2005): Effectiveness of high-intensity interval training for the rehabilitation of patients with coronary artery disease. American Journal of Cardiology. 95. 1080-1084. o. DOI:.org/10.1016/j.amjcard.2004.12.063

Warburton, D.E.- Nicol, C.W.- Bredin, S.S. (2006): Health benefits of physical activity: the evidence. Canadian Medical Association Journal, 174. 6). 801-809. DOI:: 10.1503/ cmaj.051351

Whaley, M.W. (2006): American College of Sports Medicine. ACSM's Guidelines for Exercise Testing and Prescription, 7th ed. Philadelphia: Lippincott Williams \& Wilkins, 21-29, 139-148, 165-167. o.

Williams, P.T. (2001): Physical fitness and activity as separate heart disease risk factors: a meta-analysis. Medicine \& Science in Sports \& Exercise. 33: 754-761. o.

Williams, C.B. - Zelt, J.G.E. - Castellani, L.N. - Little, J.P. - Jung, M.E. - Wright, D.C. (2013): Changes in mechanisms proposed to mediate fat loss following an acute bout of high-intensity interval and endurance exercise. Applied Physiology, Nutrition and Metabolism. 38. 2. 1236-1244. o. DOl:: 10.1139/apnm-2013-0101.

Wingfield, H.L. - Smiths-Ryan, A.E. - Melvin, M.N. - Roelofs, E.J. -Trexler, E.T. - Hackney, A.C. - Weaver, M.A. - Ryan, E.D. (2015): The acute effect of exercise modality and nutrition manipulations on post-exercise resting energy expenditure and respirs and respiratory exchange ratio in women: a randomized trial. Sports

Whyte, L.J. - Gill, J.M. - Cathcart, A.J. (2010): Effect of 2 weeks of sprint interval training on health-related outcomes in sedentary overweight/obese men. Metabolism, 59. 10. 14211428. o. DOI:: 10.1016/j.metabol.2010.01.002. 